\title{
Gümrük İdaresinden Hizmet Alan Firmaların Karşılaştığı Etik Dışı Davranışlar: Mersin İli Örneği ${ }^{a}$
}

\author{
Hüseyin SAİN ${ }^{b}$, Sezen BOZYİĞİTcd
}

\section{Özet}

Anahtar Kelimeler

Etik

Etik değerlere bağlı olmak toplumda adalet ve güven duygularının oluşması bakımından önem taşımaktadır. Her kurumda olduğu gibi gümrük idarelerinde etik değerlere bağlı olunması devletin kayıt dışı ekonomisinin azalması ve toplumun ahlaki değerlerinin erozyona uğramaması açısından gereklidir. Bu araştırmanın amacı da, Mersin taşra gümrük idaresi ile iş yapan firmaların etik dışı davranışlar ile karşılaşıp karşılaşmadığını, karşılaştılar ise ne tür davranışlar ile karşılaştıklarını tespit etmektir. Keşifsel olarak tasarlanan araştırmanın örneklemini kartopu örnekleme yöntemi kullanılarak ulaşılan, gümrük idaresi ile iş yapan 30 firma oluşturmaktadır. Katılımcılardan veriler yüz yüze derinlemesine görüşme yöntemiyle toplanmıştır. Araştırma sonuçlarına göre, katılımcıların çoğunluğunun gümrük idaresinin tüm birimlerinde etik dışı davranışlarla karşılaştığ adam kayırmanın görüldüğü, kurumların etik dışılığı önlemek için aldığg önlemlerin yetersiz bulunduğu ortaya çıkmıştır.

\section{The Unethical Behaviors Encountered by the Firms Receiving Service From Administration of Customs: A Sample of Mersin Province}

Abstract

Being dependent on ethical values is important for the feeling of justice and trust in society. As in every institution, in compliance with the ethical values in the customs administrations is important for the declining of state's informal economy and the corruption of the moral values of society. The purpose of this research is to find out whether companies that work with Mersin customs administration meet unethical behaviors or not, if so, the research aims to find out what kind of behaviors they meet. Using the snowball sampling method, the sample of the exploratory research is composed of 30 companies that are working with the customs administration. Participants were interviewed faceto-face through in-depth interviews. According to the results of the research, it is found that the majority of the participants were exposed to unethical behaviors in all the units of the customs administration. Also, privilege is the most observed unethical behavior. It is understood that, the measures taken by the institutions to prevent unethical behaviors are insufficient.
Keywords

Ethic

Unethical Behavior

Customs Administration

About Article

Received: 15.10.2018

Accepted: 10.06 .2020

Doi: $10.18026 /$ cbayarsos.470752

\footnotetext{
a "Gümrük İdaresinden Hizmet Alan Firmaların Etik Dışı Davranışlara Bakış Açılarının Belirlenmesi: Mersin İli Örneği “" isimli yüksek lisans tezinden üretilmiştir.

bORCID: 0000-0002-8816-045X

c İletişim yazarı: sbozyigit@tarsus.edu.tr.

d Doç. Dr., Tarsus Üniversitesi, ORCID: 0000-0002-0951-3588.
} 


\section{Giriş}

Etik; kültür, değerler ve normlarla yakından ilişkili bir kavramdır. Hatta özünde adalet, eşitlik, tarafsızlık ve doğruluk gibi ilkeleri de barındırmaktadır. Kaplan (2009: 344), etiğin bireysel veya toplumsal ilişkiler dahilinde sergilenen davranışların, değer yargılarının göz önüne alınarak neyin iyi, neyin kötü, neyin doğru, neyin yanlış olduğunu ahlaki açıdan araştıran bir disiplin olduğunu belirtmektedir.

Etik dışı davranışlar ise, toplumun ahlaki değerlerinin ihlal edilmesi veya etik ilke ve kuralların uygulanmaması olarak açıklanabilmektedir. Ayrımcılık, ihmal, görevi kötüye kullanma, yolsuzluk, sömürü ve rüşvet etik dışı davranış türlerindendir. Etik dışı davranışların varlığı toplumun ahlaki olarak yozlaşmasına, toplumda güvenin azalmasına neden olmakta ve ekonomi üzerinde ciddi anlamda olumsuz etkiler yaratmaktadır. Bu tür davranışlar verimli ve istikrarlı ekonomilerin oluşmasına engel olmasının yanında, ekonomik kalkınmanın ivme kaybetmesine, adil gelir dağılımının ortadan kalkmasına ve ekonomik krizlerin yaşanmasına da sebebiyet vermektedir. Etiksel problemlerin ekonomi üzerinde yarattığı bu olumsuz etkiler beraberinde yatırımların, ekonomik hacmin ve toplumsal refah düzeyinin azalmasına, işsizliğin ve enflasyonun ise artmasına neden olmaktadır. Bu doğrultuda oluşan güven erozyonu da dış ticaret hacminin azalmasına yol açmaktadır.

Etik ilkeler her alanda söz konusudur. İnsanlar yaptıkları meslek ne olursa olsun etik davranmak zorundadırlar. Bu bağlamda meslek etiği, herhangi bir meslek gurubunda çalışan personelin uyması veya kaçınması gereken tutum ve davranışlar bütünü olarak tanımlanmaktadır (Çevikbaş, 2006: 269). Her mesleğin kendine has nitelikleri ve gereklilikleri bulunmakla birlikte meslek, çalışanlarına görev ve sorumluluk yüklemektedir. Çalışanlar, ahlaki bir gereklilikle liyakatli olup mesleği için elinden gelenin en iyisini yapmalıdır. Tüm bunlar hem etik değerler doğrultusunda hem de meslek onurunun korunması bağlamında önem arz etmektedir (Çalık, 2012: 12).

Kamu çalışanları da etik ilkelere uymak zorundadırlar. Kamuda çalışanların yaptıkları etik dışı davranışlar vatandaşların devlet kurumlarına olan güvenlerinin azalmasına neden olmakta ve kamu kurumları hakkında kötü algılar oluşturmaktadır. Bu nedenle Öktem ve Ömürgönülşen (2005:232), etik kurallara uymanın kamuda ayrı bir önem taşıdığını ve kamu çalışanlarının hizmet sunumu esnasında uyması gereken ilke ve mevzuatlar bütününün kamu etiğini oluşturduğunu ifade etmektedirler. Kamu etiği, kamu çalışanlarının vatandaşlara tarafsız, zamanında, etkili ve verimli bir şekilde hizmet sunumunu gerçekleştirmesini içermektedir. Kamu Etik Kurulu'nun kurulması, etik eğitimlerin verilmesi, mevzuata ilişkin düzenlemelerin yapılması, etik komisyonların oluşturulması kamu yönetiminin etik değerlere ne kadar önem verdiğinin bir göstergesidir.

Türkiye'de etik konusunda yapılan çalışmalar (Adaman vd. 2003; TESEV, 2015; TEID, 2016) vatandaşların gözünde bazı kurumların etik bakımından kötü olarak algılandığını göstermektedir. Bu kurumlardan bir tanesi de gümrük idareleridir. Diğer kamu kurum ve kuruluşlarında olduğu gibi gümrük idarelerinde de etik değerlere bağlllık önem arz etmektedir. Ancak gümrük idareleri yüz yüze ilişkilerin yoğun olduğu kurumlardan olduğu için burada etik dışı davranışlarla daha sık karşılaşıldığı dile getirilmektedir (Pustu, 2011: 241). Ayrıca her geçen gün artan dış ticaret hacminin de etik dışı davranışlarda rol oynadığı düşünülmektedir. Daha önce etikle ilgili yapılan bazı çalışmalarda (Adaman vd. 2003; 
Akçay, 2009; TESEV, 2015; TEID, 2016) gümrük idarelerinden bahsedilse de gümrük idarelerinde etik konusunu detaylı olarak ele alan çok fazla çalışmaya (Ateş vd., 2009; Pustu, 2011; Çalık, 2012) rastlanılmamıştır. Ancak çeşitli gazete haberleri (TRT, 07.02.2020; Hürriyet, 13.03.2018; Dünya Bülteni, 10.05.2015), TESEV (2015) verileri ve Uluslararas1 Şeffaflık Örgütü raporları $(2014,2016)$ gümrük idarelerinde etik dışı davranışların olduğunu ortaya koymaktadır. Bu nedenle, bu araştırmanın amacı Mersin taşra gümrük idaresi ile iş yapan firmaların etik dışı davranışlar ile karşılaşıp karşılaşmadığını, karşılaştılar ise ne tür davranışlar ile karşılaştıklarını tespit etmektir. Araştırmada firmaların, gümrükte yaşadıkları etik dışı davranışların kaynakları araştırılarak, etik dışı davranışların önlenebilmesi için yapılması gerekenler de irdelenmiştir.

Gümrük idarelerinde etik değerlere bağlılık; meslek onurunun korunması, ekonomik kayıpların önlenmesi, kayıt dışı ekonominin azalması, adil gelir dağılımı, devlet eliyle korunan pozitif hukuk kurallarına riayet edilmesi ve güven ortamının oluşması bakımından önem arz etmektedir. Etik dışı davranışların tespit edilmesi de devletteki yatırım ve gelişmenin artmasını, ekonomik kalkınmanın önündeki engellerin, kayıt dışı ekonominin yarattığ 1 tahribatın ve topluma, devlete yüklenen maliyetlerin azaltılmasını sağlayarak devlete ve kurumlara olan güveni arttıracaktır. Tüm bu nedenlerle araştırma sonuçlarının hem etikle ilgili alanyazıne hem de bu konu ile ilgilenen tüm paydaşlara katkı sağlayacağ düşünülmektedir.

Araştırma beş bölümden oluşmaktadır. Araştırmanın konusu hakkında genel bilgilerin verildiği giriş kısmından sonra araştırmanın ikinci bölümünde etik ve etikle ilgili temel kavramlar, gümrük ve etik konusunda yapılan çalışmalar ele alınmıştır. Araştırmanın üçüncü bölümü olan yöntem kısmında araştırmanın veri toplama yöntemi, çalışma grubu, geçerlik-güvenirlik bilgileri açıklanmıştır. Dördüncü bölümde araştırma bulguları, beşinci bölümde bulguların tartışıldığı sonuç ve tartışma yer almıştır.

\section{Alanyazın Taraması}

Bu bölümde etik kavramına, gümrük ve etik konusunda yapılan çalışmalara yer verilmiştir.

\section{Etik Kavramı}

Etik, toplumsal ilişkilerin ideal bir yapıya ulaşabilmesi için kültürel yapının, değer yargılarının, hukuk kurallarının, liyakat ilkelerinin yaşam içerisinde sistematik olarak vücut bulmasıdır. Etik kavramı Yunancadaki “ethos" sözcüğünden gelmektedir. Ethos kelimesi birbirinden farklı anlamları içinde barındırmaktadır. Kelime Yunancada çoğul olarak kullanıldığında bireyin anayurdu, aidiyetini hissettiği yer veya memleket anlamına gelmektedir. Tarihsel olarak değerlendirildiğinde ise kavramın geçmişten günümüze gerek yazılı kaynaklarla gerek dilden dile süre gelen duyumlarla şekillenen alışkanlıkları, gelenek görenekleri, töreleri kısaca kültürel değerleri kapsadığı görülmektedir (Yılmaz, 2012:5). Buna karşın Türkçede etik kavramının gerek akademik alanyazında gerekse toplumun günlük kullanımında genel olarak ahlak sözcügünün yerine kullanıldı̆̆ı dikkat çekmektedir. Oysaki ahlak, insanoğlunun tavır ve davranışlarının eyleme yani pratiğe dönüşmüş haliyken, etik ise bu davranışsal özelliklerin eyleme dönüşmemiş hali diğer bir ifadeyle teorisidir (Cevizci, 2002: 8).

Etik bireysel ve meslek etiği olarak ikiye ayrılmaktadır. Bireysel etik, bireyin toplumsal değer yargılarını benimsemesinden ziyade bu değer yargılarının yaşam alanının tamamına yansıyacak şekilde yani sadece teoride değil yaşam pratiğinde de var olmasıyla anlam 
kazanmaktadır. $\mathrm{Bu}$ belirtilenlere bağlı olarak bireysel etik,bireyin davranışlarını şekillendiren değer yargılarına dair bilinci, kişiler arasında karşılıklı uyulması gereken kuralları ve yükümlülükleri açıklamaktadır (Aktan, 1996: 118).

Meslek etiği ise, kavramsal olarak etiğin diğer bir alt dalıdır. Başka bir ifadeyle etik, meslek etiğini içinde barındırmaktadır. Meslek etiği sadece belirli alanları değil, bütün alanları kapsamaktadır. Çalışanlar mesleklerini ifa ederken ahlaki doğrultuda hem çalışılan kurumun hem de personelin zarar görmemesi için yanlışların önlemesi gerekmektedir (Tepe, 2004: 23). Meslek etiği, herhangi bir mesleği icra eden kişilerin meslekleri ile ilgili eylem ve işlemlerde uyması gereken kurallar bütünüdür. Bu kurallar, söz konusu mesleğin içinde yürütüldüğü toplumsal genel geçer değerler ile meslekle ilgili evrensel kabul gören kurallardan oluşmaktadır. Herhangi bir meslekle ilgili etik değerlerin oluşması için toplum içerisinde mesleki etik ilkeleri belirleyecek ve bu ilkelerin denetlenmesini ve devamını sağlayacak mesleki gruplara ihtiyaç vardır (Çevikbaş, 2006: 69).

Etik kavramı, etik davranışların yanı sıra etik dışı davranışları da akla getirmektedir. Etik dışı davranışlar, sürdürülebilir toplum ideali doğrultusunda hukuk sisteminin, kültürel değerlerin ve inanç sistemlerinin göz ardı edilmesiyle, topluma zarar veren sonuçlar ortaya çıaran illegal ve ahlak dışı tutum ve davranışları kapsamaktadır (Özdevecioğlu, 2005: 96). Etik olmayan davranışlar kurumları, çalışanların kurumlarına sadakatini, moral ve motivasyonu olumsuz etkilemektedir. Rüşvet, irtikap, zimmet, yolsuzluk, kayırmacılık, nepotizm ve rant kollama başlıca etik dışı davranışlardır.

a) Rüşvet: En yaygın etik dışı davranışların başında gelen ve genel itibari ile maddi içeriği olan rüşvet, çalışan personelin yaptığı işin sunumunu gerçekleştirdiği esnada görev ve yetkilerini kendi çıkarları doğrultusunda kötüye kullanarak, ilgili kişi veya işletmelere ayrıcalık tanıyıp karşılı̆̆ında para ve para benzeri çıkarlar sağlamasıdır (Aktan, 2001: 53).

b) Irtikap: İrtikap, görevin kamu personeline getirdiği prestijin kötüye kullanılıp herhangi bir kimseyi kendi menfaati doğrultusunda zorlayarak veya kişinin hatasından faydalanarak yarar elde edilmesidir (Hakeri, 2006: 315).

c) Zimmet: Zimmet etimolojik olarak Arapça kökenli bir sözcük olup kişinin emanet edilen bir ürünü kendisininmiş gibi kullanması veya kendisine emanet olarak verilen bir şeyi aşırması anlamlarını taşımaktadır. Zimmet alanyazında aynı zamanda hırsızlıkla eş anlamlı olarak da kullanılmaktadır (Aktan, 2002: 57).

d) Yolsuzluk: Kamu çalışanlarının yapmaması gereken eylemlerin içinde bulunması veya yapması gereken işlemleri mevcut prosedürlerin öngördüğü süreçten daha kısa bir zaman diliminde yapması karşılığında çıkar sağlaması yolsuzluk olarak tanımlanmaktadır (Özsemerci, 2003: 4).

e) Kayırmacılık: Kayırmacılık, kamu çalışanlarının sübjektif değer yargılarıyla kendi yakın çevresinden olan eş-dost ve akrabalarına ayrıcalık tanımasıdır. Kayırmacılık toplumun kullandığı günlük dildeki 'torpil' sözcüğünün eş anlamlısıdır. 
f) Nepotizm: Nepotizm, kamu çalışanlarının sahip olduğu mesleki nüfuzu, yasa dışı kullanarak hizmet sunumu noktasında akrabalarına ayrıcalık tanıması ve kayırması anlamına gelmektedir. Herhangi bir kimsenin kişisel yetenekleri, eğitimi ve becerileri göz ardı edilerek yani diğer bir ifadeyle alternatif bireylerin bilgi ve becerileri görmezden gelinerek tercihlerin akrabalardan yana kullanılması nepotizmdir (Aktan, 1999: 19).

g) Rant Kollama: Devlet tarafından 'yapay' olarak yaratılan ekonomik bir transferi elde etmek için baskı ve çıkar gruplarının giriştikleri faaliyetlere ve bu amaca ulaşmak için yapmış oldukları harcamalara ise "Rant Kollama" adı verilmektedir (Aktan, 1993: 121).

Etik dışı davranışların ortaya çıkmasında birden fazla neden vardır. Etik dışı davranışları etkileyen faktörler genel hatlarıyla üç ana başlık altında toplanabilir. Bu faktörler;

a) Bireysel Özelliklerden Dolayı Oluşan Nedenler: Bireysel değer yargıları, kişinin etik değerler sistemine ve toplumun değer yargılarına bakış açısını şekillendiren faktörlerden, kişinin önceliklerinden ve deneyimlerinden oluşmaktadır. Bir başka ifadeyle kişinin etik değerler doğrultusundaki duyarlılığını ve bu duyarlılığın boyutunu kişinin sahip olduğu değer yargıları, öncelikleri ve deneyimleri belirlemektedir. Örneğin kişisel çıkarlarını her şeyin üzerinde gözeten bireylerin tutum ve davranışlarında etik dışı davranışlara başvurma olasılığı yüksektir (Arslan ve Berkman, 2009: 83).

b)Örgütsel Nedenler: Toplumun artan ihtiyaçlarını karşılamak adına devlet aygıtının mal ve hizmet arzının artması, diğer bir ifadeyle kamusal alanın büyümesi örgütsel büyümeyi ve istihdam problemlerini meydana getirmiştir. Devlet aygıtının mal ve hizmet arzının, toplumun artan talebini karşılayamaması öncelikli olarak yolsuzluğa, beraberinde ise etik dışı davranışların oluşmasına sebebiyet vermektedir (Köprü, 2007: 32-33).

c) Ekonomik ve Toplumsal Nedenler: Geleneksel toplum modellerinde, ilişkiler genel itibariyle aile, akraba ve eş-dost çevresi doğrultusunda örgütlenmeyi ve dayanışmayı geçerli kılmaktadır. Bu doğrultuda kamu görevini icra eden kamu personeli söz konusu çevrenin baskısı altındadır. Kamu personelinin icra ettiği mesleğin hizmet sunumu esnasında söz konusu çevre, geleneksel kültürün etkisiyle iltimas geçilmesini talep edebilmekte, dayanışma adı altında söz konusu taleplerin gerçekleşmesi de beraberinde etik dışı tutum ve davranışları doğurmaktadır (Özsemerci, 2003: 61-62).

Yolsuzluk Algısı Endeksi 2019'a göre, Türkiye 39 puan ile 180 ülke arasından 91. sırada yer alırken, Yeni Zelanda ve Danimarka 87 puan ile ilk sıralarda, 9 puan ile Somali, 12 Puan ile Güney Sudan ve 13 puan ile Suriye de son üç sırada bulunmaktadır. (https://www.transparency.org 10.04.2020). 2013-2019 arasinda en çok puan kaybeden ülkeler ise Macaristan, Türkiye ve Saint Lucia'dır (https://www.transparency.org, 10.04.2020). 


\section{Gümrük ve Etik Konusunda Yapılan Çalışmalar}

Türkiye'deki bazı kurumlarda etik dışı davranışların daha yoğun olarak yaşandığına dair toplumda algılar mevcuttur. Örneğin 2016 yılında Türkiye' deki yolsuzluk algısını incelemek üzere yapılan "Yolsuzluk Raporu 2016"ya göre gümrük memurlarının toplumun büyük bölümü tarafından yolsuzluğa karıştığı düşünülen meslek gruplarından birisi olduğu ortaya çıkmıştır. Akçay (2009), Türkiye'de 2000-2001 yılları arasında yapılan yolsuzluk operasyonlarının büyük bir kısmının gümrüklerle ilgili olduğunu, "Paraşüt, Hayal, Matador, Bufalo, Sis, Fırtına, Puro, Kartal, Balina, Hasat" ismi verilen yolsuzluk operasyonlarında trilyonlarca liralık yolsuzluklar yapıldığını ifade etmektedir. Bu çalışma dışında doğrudan gümrük ve etik algısını inceleyen veya yaptığı araştırma neticesinde bununla ilgili sonuçlara ulaşan başka çalışmalar da mevcuttur. Aşağıda bu çalışmalardan bazılarına yer verilmiştir.

Adaman, Çarkoğlu ve Şenatalar (2003), “İşs Dünyası Gözünden Türkiye'de Yolsuzluğun Nedenleri ve Önlenmesine İlişkin Öneriler" başlıklı araştırmalarında, ankete katılan iş adamlarının büyük çoğunluğunun rüşvet ve yolsuzlukların en yaygın olduğu kurum olarak gümrükleri gördügünü, yarıdan fazlasının ise gümrüklerde kendisinden açıkça kural dışı ödeme ya da hediye istendiğini ortaya koymuşlardır.

Gümrük Müsteşarlığ1 tarafından yapılan “Gümrüklerde Yolsuzlukla Mücadele Dürüstlük ve Etik İlkeler" başlıklı çalışma grubu raporunda (2008), sık sık değiştirilen, farklı yorumlara neden olan ve çok sayıda yasal metinden oluşan mevzuatın varlığının ve karmaşıklığının, iş tanımları, görev, yetki ve sorumlulukların net bir şekilde belli olmamasının, bir işi birden fazla birimin yapmasının, kurum kültürü ve aidiyet duygusunun güçlü olmamasının, yetersiz iletişimin, sayısal olarak yeterli ve nitelikli personel istihdamı konusunda yaşanan problemlerin, ücret adaletsizliğinin etik yapının önündeki temel engeller olduğu belirtilmiştir.

Ateş ve diğerlerinin (2009) sekiz gümrük ve iki gümrük başmüdürlügünde gümrük hizmetlerindeki etiği araştırdığı çalışmada, vatandaşların yaklaşık yarıdan fazlasının gümrük müdürlüklerinde az ya da çok yolsuzluk ve rüşvetin bulunduğuna inandığı, çalışanların yarısından fazlasının çeşitli sıklıklarda etik dışı davranışları yapmak zorunda kaldığı belirtilmektedir. Çalışmada ayrıca çalışanlar tarafından en yaygın olarak görülen etik dışı davranışların kırtasiye vb. sarf malzemelerinin iş takipçilerince temin edilmesi, vatandaşların gümrük müşavirlerine ve iş takipçilerine yönlendirilmesi ve akraba, eş, dost, hemşeri, siyasal görüş vb. bir nedenle ayrımcılık veya kayırmacılık yapılması olduğu tespit edilmiştir (Ateş ve diğerleri, 2009).

TESEV tarafından yayımlanan "Yolsuzlukla Mücadele Türkiye Değerlendirme Raporu" 2015 verilerine göre, yolsuzluğun kurumlardaki yaygınlık seviyesinde kamu kurumları ve özel sektör de dahil olmak üzere, gümrük idareleri en çok yolsuzluğun yapıldığ 1 kurum olarak ikinci sırada yer almıştır. Rapora (2015) göre, polis, belediye, vergi, gümrük memurları ve belediye meclis üyeleri problemleri çözme karşılığında para veya hediye talebinde bulunan görevliler olarak düşünülmektedir.

Etik ve İtibar Derneği'nin (TEID) 2016 yılında Türkiye'nin en büyük ilk 500 kurumunun yöneticileri ve çalışanları ile TEID üyelerinin katılımıyla yaptığ 1 "Yolsuzluk Alg1 Araştırması" sonuçlarına göre, özel sektöre kıyasla belediye, siyasi parti ve gümrüklerde yolsuzluğun daha yaygın olduğuna inanıldığı ve yolsuzluğun çok yaygın olduğu düşünülen 
sektörlerin başında lojistik ve gümrük sektörünün geldiği tespit edilmiştir (www.tice.org.tr. 31.03.2018).

Tüm bu çalışmalar dışında basında da gümrük idarelerinde karşılaşılan etik dışı davranışlarla ilgili haberlerin yer aldığı görülmektedir. Örneğin 10.05 .2015 tarihli gazete haberine göre, İpsala sınır kapısında Edirne Emniyet Müdürlüğü Kaçakçılık ve Organize Suçlarla Mücadele Şubesi ekiplerince gerçekleştirilen operasyonda dokuz gümrük muhafaza memuru gözaltına alınmış, savcılık sorgusundan sonra dört gümrük muhafaza memuru serbest birakılırken, diğer beş gümrük muhafaza memuru "rüşvet alma ve görevi kötüye kullanma" suçlarından tutuklanmıştır (www.dunyabulteni.net, 02/01/2018). 13.03.2018 tarihli gazete haberine göre, Türkiye-Nahçıvan arasındaki Dilucu Kapısı'nda yapılan yolsuzluk iddiasıyla 40 gümrük çalışanının; hayali ihracat, evrakta sahtecilik, rüşvet ve kaçakçılık suçlamasıyla gözaltına alındığı belirtilmiştir (hurriyet.com.tr, 08/04/2020).

Gümrük ve etik ile ilgili yurtdışında yapılan çalışmalar da mevcuttur. Miloshoska ve Vasileska (2012) Makedonya'daki gümrük personelinin mesleki dürüstlüğünü inceledikleri çalışmalarında, 182 gümrük memuruna karşı açılan 216 kayıtlı ceza davasından 57'sinin nihai ceza ile sonuçlandığını, 24'ünün temyizde olduğunu belirtip 2010 yılında gümrük çalışanlarıyla ilgili sahte beyan, görevin ihmali, rüşvet, kaçakçlığa yardım gibi suçlamalarda bulunulduğunu ifade etmiştir. Onogwu (2018), Haziran 2015- Mayıs 2016 yılları arasında Nijerya'daki memurlara 400 milyar Naire rüşvet dağıtıldığını, vergi ve gümrük memurlarının bu rüşvetin yüzde 27'sini alıp tüm memurlar arasında dördüncü sırada olduğunu, yolsuzluğun gümrük hizmetlerinin etkinliğini güçlü bir şekilde azalttığını ancak liman altyapılarının kalitesinin iyileştirilmesinin ülkelerdeki gümrük hizmetlerinin etkinliğini artıracağını vurgulamıştır. Jancsics (2019) çalışmasında, gümrükte yaşanan etik dışı davranışların hem müşteriden hem de gümrük çalışanından kaynaklanabileceğini, sınırda, malların hala fiziksel olarak denetlenmesi gerektiğinden doğrudan temastan kaçınılamayacağını, bu fiziksel temasın da yolsuzluğa fırsat yarattığını, memurların sınırda yolsuzluk firsatlarını çoğaltan yüksek sayıda işlemle ilgilendiğini ortaya koymuştur. 07.02.2020 tarihli gazete haberine göre de, Bulgaristan İçişleri Bakanlığınca yapılan açıklamada; Bulgaristan-Sırbistan gümrük kapısı Kalotina'da gerçekleştirilen yolsuzluk operasyonunda 30 Bulgar gümrük memurunun tutuklandığ 1 ve çok sayıda sınır polisinin gözaltına alındığı ifade edilmiştir (www.trthaber.com, 08/04/2020).

Gümrük idaresindeki etik dışı davranışlar uluslararası ticaret ve lojistik süreçlerini de olumsuz bir şekilde etkilemektedir. Uca vd. (2019:1234), bir ülkenin gümrüklerinde ve lojistik sürecinde yolsuzluk ve rüşvet gibi olayların olmasının ülke içerisinde ithalat ve ihracat yapan firmaların maliyetlerine yansıdığını, bu maliyetlerin de ülke ekonomisini olumsuz yönde etkilediğini dile getirmektedirler. Bu konuda yapılan çalışmalardan bazılarına aşağıda yer verilmiştir.

Ali ve Mdhillat (2015), çalışmalarında rüşvetle uğraşan firmaların gümrük yetkilileriyle daha fazla zaman geçirdiklerini, bu nedenle yolsuzluğun ticareti engellediğini vurgulamaktadırlar. Benzer şekilde, yüksek etik standartlara sahip ülkelerden gelen firmaların, yolsuzluğun yaygın olduğu bir ülke ile ticaret yapmaları halinde kötü bir üne maruz kalıp hem iç hem de dış pazarlardaki tüketicilerini kaybedebileceklerini, bu nedenle de bu ülkelerin, başka bir yerde yüksek kârlılık ihracatı olasılığına rağmen, benzer etik standartlara sahip ülkelerle uluslararası işlemler yapmayı tercih edebileceğini belirtmektedirler (Ali ve Mdhillat, 2015:110). 
Gezikol ve Tunahan (2018), çalışmalarında kısa vadede rüşvetin işleri hızlandırıp ticareti kolaylaştırdığı yanılgısı olsa da uzun dönemde rüşvetin maliyetinin belirsizliği nedeniyle dış ticareti azalttığını, ek olarak vergi artışı nedeniyle ülkelerin korumacı yaklaşım sergilemesinin yolsuzluğu artırdığını bunun da dış ticaret üzerinde olumsuz etki yaratacağını dile getirmiştir.

Uca vd. (2019), yolsuzluk algısının gayrisafi yurt içi hasıla üzerine etkisinde lojistik performans ile küresel rekabetin aracı rolünü inceledikleri çalışmalarında da bir ülkenin lojistik performansını artırıcı yatırımların yapılmasının tek başına yeterli olmadığını, aynı zamanda yolsuzlukla da mücadele edilmesi gerektiğini ifade etmişlerdir.

\section{Araştırmanın Yöntemi}

Bu bölümde araştırmanın sorusu, evreni ve çalışma grubu, veri toplama yöntemi, geçerlik ve güvenirlik bilgilerine yer verilmiştir.

\section{Araştırma Sorusu}

Araştırma nitel bir araştırma olduğu için hipotez oluşturulmamış, bunun yerine araştırma sorusu sorulmuştur. Araştırmanın bir ana iki alt sorusu mevcuttur. Araştırmanın alt soruları ana sorunun devamı ve açıklayıcısı olarak oluşturulmuştur. Araştırmanın ana sorusu aşağıdaki gibidir;

" Gümrük idaresinde etik dışı davranışlarla karşılaşılıyor mu ?"

a)Eğer karşılaşıllıyorsa bu davranışlar nelerdir ?

b)Karşılaşılmıyorsa bu nasıl sağlanmıştır?

\section{Araştırmanın Evreni ve Çalışma Grubu}

Araştırmanın evrenini; Mersin Taşra Gümrük İdaresi ile iş yapan firmalar oluşturmaktadır. Araştırma için Mersin gümrük idaresinin seçilme nedeni, dış ticaret hacmi bakımından Mersin'in önem arz etmesidir. 2018 yılının 6 aylık döneminde Mersin Liman tesislerine operasyon için uğrayan gemi sayısı geçen yıla göre yüzde 4,3 artarak 2 bin 226'ya yükselmiş, Türkiye genelinde limanlara uğrayan gemi sayısına göre Mersin, geçen yılki 4'üncü sıradaki yerini de 2018'de de korumuştur (https://www.akib.org.tr/). Mersin Taşra Gümrük İdaresi ile iş yapan firmaların sayısı tam olarak bilinmemekle birlikte, Mersin Gümrük Müşavirleri Derneği'ne (MERGUMDER) bağlı olan 202 firmanın bulunduğu tespit edilmiştir (http://www.mergumder.org.tr, 10.02.2018). Araştırmada zaman ve maliyet kısıtlarından ötürü ana kütleye ulaşılamamış, bu sebeple örneklem seçme yoluna gidilmiştir. Araştırmada örneklem yöntemi olarak, kartopu örnekleme yöntemi kullanılmıştır.

Örneklem yöntemi olarak tesadüfi olmayan bir yöntem seçildiği için araştırmada örneklem yerine çalışma grubu kelimesinin kullanılmasının daha doğru olduğu düşünülmektedir. Nitel çalışmalarda çalışma grubu sayısı, araştırma sorusuna cevap niteliğinde olan kavram veya süreçlerin doyum noktasına ulaşmasıyla, diğer bir ifadeyle toplanan verilerin birbirini tekrar etmesiyle yakından ilişkilidir (Yıldırım ve Şimşek, 2016: 125). Bu nedenle araştırmada cevapların birbirini tekrar etmeye başladığ 130 . katılımcıdan sonra çalışma grubuna katılımcı seçme işlemine son verilmiştir. $\mathrm{Bu}$ nedenle analizler 30 katılımcının görüşlerini yansitmaktadir.

\section{Araştırmanın Veri Toplama Yöntemi}


Araştırma keşifsel bir araştırma olduğundan dolayı araştırmanın bu boyutunu ortaya koymak için nitel veri toplama yöntemlerinden yüz yüze derinlemesine görüşme yöntemi kullanılmıştır. Derinlemesine görüşme, araştırılan herhangi bir konunun detaylı bir şekilde ele alınabilmesi için açık uçlu soruların sorulup yüz yüze görüşülüp gerekli verilerin elde edilmesi için kullanılan bir yöntemdir (Tekin, 2006: 101). Bu araştırmada yarı yapılandırılmış görüşme formu tercih edilmiştir. Araştırma soruları, Özsemerci'nin (2003), Tanrıseven'in (2006), Coşkun'un (2010), Pustu'nun (2011), Yılmaz'ın (2012) ve İnal'ın (2012) çalışmalarından yararlanılarak araştırmacılar tarafından oluşturulmuştur. Katılımcılara görüşme sorusu olarak, etik dışı davranış ile karşılaşılıp karşılaşılmadı̆̆ı, eğer karşılaşılıyorsa, bu davranışların neler olduğu, nelerden kaynaklandığı, bu tür davranışlarla en çok hangi birimlerde karşılaşıldığı ve bu davranışların nasıl önlenebileceği, karşılaşılmıyorsa da bunun nedeninin ne olabileceği sorulmuştur. Araştırma soruları oluşturulduktan sonra beş katılımcı ile ön test yapılmış, katılımcılardan gelen geri bildirimler sonucu araştırmanın soru formu tekrardan düzenlenmiş ve son halini almıştır.

Katılımcılar ile olan görüşmeler 8 Haziran- 29 Ağustos 2017 tarihleri arasında yapılmıştır. Görüşme talebi için firmalar telefonla aranmış, firma yetkilileri tarafından uygun zaman belirtildikten sonra randevular alınmıştır. Katılımcılardan 12 kişi bizzat firma sahibidir, 18 kişi ise gümrük idaresiyle bire bir iş yapan saha personelinden oluşmaktadır. 30 katılımcr ile iş yerlerinde yüz yüze görüşme gerçekleştirilmiştir. Katılımcılarla yapılan görüşmeler araştırmacı tarafından not alınarak kayıt altına alınmıştır. Görüşmelerin araştırmacı tarafından not alınarak kayıt altına alınmasının sebebi, katılımcların ses kayıt cihazı kullanılmasını istememeleridir. Katılımcılarla gerçekleştirilen görüşmeler ortalama 30 ile 60 dakika arası sürmüştür.

Araştırma verileri analiz edilirken, betimsel ve içerik analizi yöntemleri kullanılmıştır. Betimsel analiz, ham verilerin okuyucuların anlayabileceği ve kullanabileceği şekle getirilmesidir (Coşkun vd., 2015: 324). Mantıksal bir sıraya konulan ve sınıflandırılan veriler, bu analiz yöntemiyle daha kolay yorumlanıp daha doğru sonuçlara ulaşılabilmesini sağlamaktadır. İçerik analizi, araştırmacının elde ettiği görüşme dökümlerinin karşılaştırma yapılabilmesi için karakterize edildiği bir yöntemdir. Temel amacı ise katılımcıların görüşlerini sistematik olarak tanımlamak ve araştırmacının toplanan verilere aşina olmasını kolaylaştırmaktır (Coşkun vd., 2015: 324).

\section{Araştırmanın Geçerliği ve Güvenirliği}

Araştırmalar ister nitel, ister nicel olsunlar sundukları verilerin inandırıcı olması gerekmektedir. Araştırmaların inandırıcı olabilmesi için ise geçerlik ve güvenirlik koşullarını sağlaması şarttır. Geçerlik ve güvenirlik birbirlerine bağlı ve araştırmaların ölçümüne dair olan kavramlardır (Türnüklü, 2000: 543).

Ulaşılan bilginin ve yargının gerçekliği anlamına gelen geçerlik için, araştırmacı tarafından elde edilen verilerin analizi ile ulaşılan sonucun doğruluğu önem arz etmektedir (Türnüklü, 2000: 552). Nitel araştırmalarda geçerlik, araştırmayı gerçekleştiren kişinin araştırılan olguyu olduğu gibi, diğer bir ifadeyle en doğal haliyle tarafsız bir şekilde sunmasıdır. Araştırmacının temel amacı araştırılan olgu veya olayla ilgili bütüncül bir resim oluşturabilmesi ve elde ettiği veriler ile ulaşılan sonuçların teyit edilmesidir (Yıldırım ve Şimşek, 2016: 269). Nitel araştırmalarda elde edilen bilgiler geçerli ise benzer türden başka bir araştırmayla birebir aynı olmasa bile benzer bilgilere ulaşma olasılığı yüksek olacaktır. Bu 
sebeple nitel araştırmalarda geçerliğin güvenirlikten daha önemli olduğu ifade edilmektedir (Yıldırım ve Şimşek, 2016: 270). Bilimsel araştırmaların geçerlik koşullarının sağlanabilmesi için verilerin hangi yöntemlerle elde edilip nasıl kullanıldığı da belirtilmelidir (Guthrie, Yongvanich ve Ricceri, 2004: 285).

Nitel araştırmada güvenirliği sağlamak nicel araştırmalarda olduğu kadar kolay değildir. Nicel araştırmalarda alfa değeri ile sağlanan güvenirlik, nitel araştırmalarda farklı yollardan elde edilmektedir. Nitel araştırmalarda durumlar gerçek kişiye ve içinde bulunulan ortama göre sürekli olarak bir değişim içindedir. Hatta aynı kişiler için zaman içerisinde bile değişebilmektedir (Yıldırım ve Şimşek, 2016: 272-273). Bu nedenle de benzer ya da aynı grubun kendini tekrarlaması yani aynı sonuçlara ulaşmak pek mümkün olmamaktadır. Bunun temel nedenlerinden biri; insan davranışlarının durağan olmayıp sürekli değişkenlik gösterip karmaşık bir yapıya sahip olması iken, diğeri ise nitel araştırmalarda araştırmayı gerçekleştiren kişilerin olayları algılama ve yorumlama biçimlerinin farklılık gösterebilmesidir (Yıldırım ve Şimşek, 2016: 272-273). Derinlemesine görüşme yönteminin kullanıldığı çalışmalarda güvenirliğin sağlanması için ön testin yapılması gerekmektedir. Yapılan ön test toplanan verilerin analiz edilmesini, soruların değerlendirilmesini ve soru formunun son halini almasını sağlamaktadır (Coşkun, vd., 2015: 92). Araştırmanın güvenirliği için araştırmacının katılımcılara aynı soruları sorması yanında, veri analizlerinin çözüm tutarlılığına da dikkat etmesi gerekmektedir (Türnüklü, 2000: 550).

Araştırmada katılımcılara soru formundaki sorular olduğu gibi sorulmuştur. Bütün görüşmeler tek bir araştırmacı tarafından gerçekleştirilmiştir. Araştırmacının görüşmeler sonucu elde ettiği veriler doğal haliyle, değiştirilmeden aktarılmıştır. Bulguların nasıl elde edildiği ve hangi analiz yöntemlerinin kullanıldığı detaylı bir şekilde açıklanmıştır. Araştırmanın bulgular bölümünde ulaşılan sonuçların doğruluğunun kontrol edilebilmesi için bazı katılımcıların verdiği cevaplardan alıntılar yapılmıştır. Yürütülen araştırma için bu hususlar göz önünde bulundurulduğunda geçerlik ve güvenirlik koşullarının sağlandığ düşünülmektedir.

\section{Bulgular}

$\mathrm{Bu}$ kısımda araştırmayla ilgili bulgulara yer verilmiştir. Katılımcılar sorulara birden fazla yanıt verdikleri için bazı tablolarda verilen cevapların toplamı katılımcı sayısından fazla çıkmıştır. 
Tablo 1. Katılımcıların Demografik Özellikleri

\begin{tabular}{lcccc}
\hline Katılımc1 & Cinsiyet & Yaş & Eğitim & $\begin{array}{c}\text { Sektör } \\
\text { Tecrübesi }\end{array}$ \\
\hline Katılımc1 1 & Erkek & 35 & Lisans & 10 \\
Katılımc1 2 & Erkek & 51 & Lisans & 30 \\
Katılımc1 3 & Erkek & 45 & Lisans & 19 \\
Katılımc1 4 & Erkek & 45 & Lisans & 16 \\
Katılımc1 5 & Erkek & 37 & Lise & 20 \\
Katılımc1 6 & Erkek & 38 & Lise & 18 \\
Katılımc1 7 & Kadın & 29 & Lisans & 4 \\
Katılımc1 8 & Erkek & 26 & Ön lisans & 1 \\
Katılımc1 9 & Erkek & 37 & Lisans & 14 \\
Katılımc1 10 & Erkek & 38 & Lisans & 12 \\
Katılımc1 11 & Kadın & 28 & Lisans & 4 \\
Katılımc1 12 & Erkek & 47 & Lise & 24 \\
Katılımc1 13 & Kadın & 31 & Lisans & 4 \\
Katılımc1 14 & Kadın & 30 & Lisans & 6 \\
Katılımc1 15 & Erkek & 36 & Lisans & 10 \\
Katılımc1 16 & Erkek & 35 & Lisans & 8 \\
Katılımc1 17 & Erkek & 29 & Lisans & 4 \\
Katılımc1 18 & Erkek & 28 & Lisans & 4 \\
Katılımc1 19 & Erkek & 28 & Lisans & 4 \\
Katılımc1 20 & Erkek & 30 & Lisans & 5 \\
Katılımc1 21 & Erkek & 31 & Lisans & 5 \\
Katılımc1 22 & Erkek & 44 & Lisans & 17 \\
Katılımc1 23 & Erkek & 54 & Lisans & 30 \\
Katılımc1 24 & Erkek & 32 & Yüksek lisans & 8 \\
Katılımc1 25 & Erkek & 28 & Lisans & 4 \\
Katılımc1 26 & Erkek & 34 & Lisans & 6 \\
Katılımc1 27 & Erkek & 39 & Yüksek lisans & 5 \\
Katılımc1 28 & Erkek & 35 & Yüksek lisans & 7 \\
Katılımc1 29 & Erkek & 42 & Ön lisans & 20 \\
Katılımc1 30 & Erkek & 26 & Yüksek lisans & 4 \\
\hline & & & \\
\hline
\end{tabular}

Tablo 1'de derinlemesine görüşme yapılan katılımcıların demografik özellikleri görülmektedir. Katılımcılar 26'sı erkek, 4'ü kadın olmak üzere 30 kişiden oluşmaktadır. Katılımcların 12'si firma sahibi, geriye kalan 18'i ise firma personelidir. Ancak bu personel bizzat gümrük idareleri ile iş yürüten saha personelidir. Katılımcıların yaş aralığ1 26-54 arasında değişmekte olup ortalama yaş 35'tir. 21 katılımcı lisans, 4 katılımcı yüksek lisans, 3 katılımcı lise ve 2 katılımcı ön lisans mezunudur. Görüşülen katılımcıların sektördeki deneyimleri 1-30 yıl arasında olsa da ortalama deneyimin 10 yıl olduğu saptanmıştır. 
Tablo 2. Birinci Soru ve Katılımcların Bu Soruya Verdikleri Cevaplar

\begin{tabular}{llll}
\hline Soru & Cevaplar & Sıklık & Yüzde \\
\hline & Toplumun benimsemediği (gayri ahlaki) & 16 & 34 \\
& davranışlar & & \\
& Kanun ihlali & 11 & 24 \\
& Genel geçer doğruların ihlali & 5 & 11 \\
& Rüşvet & 3 & 7 \\
Size göre etik dışı & Kişisel çıkarların gözetilmesi & 2 & 4 \\
davranış nedir? & Hizmetin aksatılması & 2 & 4 \\
& Yolsuzluk & 2 & 4 \\
& Adam kayırma & 2 & 4 \\
& Gelenek görenek dışı davranışlar & 2 & 4 \\
& Memurun keyfi davranışı & 1 & 2 \\
& Gereksiz samimiyet & 1 & 2 \\
& Toplam & 47 & 100 \\
\hline
\end{tabular}

Tablo 2 "Size göre etik dışı davranış nedir?" sorusuna verilen cevapları göstermektedir. Bu soruyla ilgili olarak verilen cevapların yüzde 34'ü "toplumun benimsemediği (gayri ahlaki) davranışlar", yüzde 24' ̈̈ "kanun ihlali”, yüzde 11'i "genel geçer doğruların ihlali” yüzde 7'si ise "rüşvet" şeklindedir. Bu soruya ilişkin katılımcılardan bazılarının görüşleri aşağıdaki gibidir:

"Gelenek ve göreneklerimiz dışında hareket edilmesi, usul ve kanunların ihlal edilmesi ya da toplumun benimsediği kuralların göz ardı edilmesidir." (Katılımcı 1)

"Toplum tarafından benimsenmeyen davranışların sergilenmesi etik dışı davranıştır." (Katılımc1 2)

"Toplumun ahlaki çerçevesinin ve pozitif hukuk kurallarının ihlal edilmesi etik dışı davranıştır." (Katılımcı 3)

Tablo 3. İkinci Soru ve Katılımcıların Bu Soruya Verdikleri Cevaplar

\begin{tabular}{llll}
\hline Soru & Cevaplar & Sıklık & Yüzde \\
\hline $\begin{array}{l}\text { Gümrük idarelerinde etik dişı } \\
\text { davranışların olduğunu }\end{array}$ & Evet & 21 & 70 \\
düşünüyor musunuz? & Hayır & 9 & 30 \\
& Toplam & 30 & 100 \\
\hline
\end{tabular}

Tablo 3'teki “Gümrük idarelerinde etik dışı davranış olduğunu düşünüyor musunuz?" sorusuna verilen cevaplar incelendiğinde, katılımcıların yüzde 70'inin etik dışı davranışların olduğunu, yüzde 30'unun ise olmadığını ifade ettikleri görülmektedir. Bazı katılımcıların beyan ettiği ifadeler aşağıdaki gibidir:

"Kesinlikle olduğunu düşünüyorum." (Katılımc1 7)

"Evet düşünüyorum çünkü gördü̈̆̈̈m oldu." (Katılımc111)

"Hayır düşünmüyorum." (Katılımc1 14) 
Tablo 4. Üçüncü Soru ve Katılımcıların Bu Soruya Verdikleri Cevaplar

\begin{tabular}{llll}
\hline Soru & Cevaplar & S1klık & Yüzde \\
\hline Gümrük idarelerinin en & Bütün Birimler & 12 & 57 \\
çok hangi birimlerinde etik & Gümrük Muayene Birimi & 6 & 29 \\
$\begin{array}{l}\text { dişı davranışların } \\
\text { olduğunu }\end{array}$ & Gümrük Muhafaza Birimi & 3 & 14 \\
düşünüyorsunuz? & Toplam & 21 & 100 \\
\hline Neden özellikle bu & Yetkinin kötüye kullanımı & 9 & 43 \\
birimlerde etik dışı & Ekonomik çıkar sağlama & 7 & 33 \\
davranışların olduğunu & Mükellefle yakınlık & 4 & 19 \\
düşünüyorsunuz? & Denetlenmeme & 1 & 5 \\
& Toplam & 21 & 100 \\
\hline
\end{tabular}

Tablo 4'te “Gümrük idarelerinin en çok hangi birimlerinde etik dışı davranışların olduğunu düşünüyorsunuz?" sorusuna verilen cevaplar görülmektedir. 21 katılımcının yüzde 57'si "bütün birimler", yüzde 29'u "gümrük muayene birimi" ve yüzde 14'ü ise "gümrük muhafaza birimi" cevabını vermiştir. Tablodan da anlaşılacağı üzere katılımcıların yarısından fazlası gümrük idarelerinin bütün birimlerinde etik dışı davranışların olduğunu ifade etmişlerdir. Katılımcıların bu birimlerde etik dışı davranışların olduğunu düşünme nedenleri ise yüzde 43 yetkinin kötüye kullanılması, yüzde 33 ekonomik çıkar sağlama, yüzde 19 mükellefle kurulan yakınlık ve yüzde 5 ise denetlenmemedir. Mükelleflerle kurulan yakınlıktan ötürü ortaya çıkan etik dışı problemler daha çok gümrük muayene biriminde kendini gösterirken; yetkinin kötüye kullanılması, ekonomik çıkar sağlama ve denetlenmeme ise gümrük muayene birimi, gümrük muhafaza birimi de dahil olmak üzere bütün birimleri kapsamaktadır. Bazı katılımcıların bu konu hakkındaki görüşleri şu şekildedir:

"Muayene biriminde daha çok etik dışı davranış olduğunu düşünüyorum. Çünkü muayene memurları yakınlık kurduğu mükelleflere öncelik tanımakta (adam kayırma) bu da dolaylı olarak maddi ve manevi çıkarların sağlanmasına sebebiyet vermektedir." (Katılımcı 5)

"Hemen hemen her biriminde bulunmaktadır. Gümrük idarelerine bağlı olan birimlerin çoğunun belirtilen kurallara ve kanunlara uymadı̆̆ı kanaatindeyim." (Katılımc1 8)

"Gümrük idarelerinin hemen hemen her biriminde etik dışı davranışların olduğunu düşünüyorum. Nedeni ise denetlenmemeleridir." (Katılımc1 10)

Tablo 5. Dördüncü Soru ve Katılımclların Bu Soruya Verdikleri Cevaplar

\begin{tabular}{llll}
\hline Soru & Cevaplar & Sıklık & Yüzde \\
\hline \multirow{3}{*}{ Size göre en çok } & Adam kayırma & 14 & 50 \\
görülen etik dişı & Yı̈vet & 10 & 35 \\
davranışlar nelerdir? & Haksız kazanç elde etme & 2 & 7 \\
& Yolsuzluk & 1 & 4 \\
& Toplam & 28 & 4 \\
& & & \\
\hline
\end{tabular}

Tablo 5'te "Size göre en çok görülen etik dişı davranışlar nelerdir?" sorusuna verilen cevaplar görülmektedir. 21 katılımcının verdikleri cevaplar sırasıyla şu şekildedir; 14 kişi 
“adam kayırma”, 10 kişi "rüşvet”, 2 kişi "yıldırma politikaları" ve 1'er kişi “haksız kazanç elde etme ve yolsuzluk". Katılımcılardan bazılarının görüşleri aşağıdaki gibidir:

"Bana göre en çok görülen etik dışı davranışlar haksız kazanç ve adam kayırmadır." (Katılımcı 13)

"Rüşvet ve adam kayırma." (Katılımcı 4)

"En çok görülen etik dışı davranışlar yıldırma politikaları, rüşvet ve adam kayırmadır." (Katılımc1 9)

Tablo 6. Beşinci Soru ve Katılımcıların Bu Soruya Verdikleri Cevaplar

\begin{tabular}{llll}
\hline Soru & Cevaplar & Sıklık & Yüzde \\
\hline & Eğitimsizlik & 7 & 23 \\
& Yetki ve sorumluluğun kötüye kullanılması & 5 & 16 \\
Size göre etik dışı & Daha çok kazanma arzusu & 5 & 16 \\
davranışların & Ahlaki yoksunluk & 4 & 13 \\
nedenleri neler & Maaşların yetersizliği & 4 & 13 \\
olabilir? & Vergilerin yüksek oluşu & 3 & 10 \\
& Aşırı hırs ve umursamazlık & 2 & 6 \\
& Denetim yetersizliği & 1 & 3 \\
& Toplam & 31 & 100 \\
\hline
\end{tabular}

Tablo 6'da"Size göre etik dışı davranışların nedenleri neler olabilir?” sorusuna verilen cevapların yüzde 23'ünü "eğitimsizlik", yüzde 16'sını "yetki ve sorumluluğun kötüye kullanılması", yüzde 13'ünü "ahlaki yoksunluk ile maaşları yetersizliği” cevapları oluşturmaktadır. Vergilerin yüksek oluşu, aşırı hırs ve umursamazlık ve denetim yetersizliği ise diğerlerine göre yüzdesi daha düşük olan cevaplardır. Bazı katılımcıların görüşleri aşağıdaki gibidir:

"Bana göre gümrük idarelerindeki etik dışı davranışların temel sebebi gümrük vergilerinin yüksek olmasıdır." (Katılımc1 17)

"Bana göre etik dışı davranışın temel nedeni eğitimsizliktir." (Katılımcı 18)

"Gümrük vergilerinin yüksek oluşudur." (Katılımc1 19)

Tablo 7. Altıncı Soru ve Katılımcların Bu Soruya Verdikleri Cevaplar

\begin{tabular}{|c|c|c|c|}
\hline Soru & Cevaplar & Siklık & Yüzde \\
\hline \multirow{3}{*}{$\begin{array}{l}\text { Etik dışı davranışların } \\
\text { önlenmesine yönelik } \\
\text { olarak yapılan çalışmalar } \\
\text { yeterli midir? }\end{array}$} & Yeterli değildir & 21 & 100 \\
\hline & Yeterlidir & 0 & 0 \\
\hline & Toplam & 21 & 100 \\
\hline \multirow{7}{*}{$\begin{array}{l}\text { Bu konudaki önerileriniz } \\
\text { nelerdir? }\end{array}$} & Denetim mekanizmasının arttırılması & 13 & 37 \\
\hline & Etik eğitiminin verilmesi & 8 & 23 \\
\hline & Erdemli bireyler yetiştirmek & 8 & 23 \\
\hline & Gümrük vergilerinin düşürülmesi & 3 & 8 \\
\hline & Maaş ve ücretlerin arttırılması & 2 & 6 \\
\hline & Liyakat ilkesine bağlılık & 1 & 3 \\
\hline & Toplam & 35 & 100 \\
\hline
\end{tabular}


Tablo 7'de ilk olarak “Etik davranışların önlenmesine yönelik yapılan çalışmalar yeterli midir?" sorusuna verilen cevaplar görülmektedir. Bu soruya 21 katılımcının 21'i de "yeterli değildir" cevabını vermişlerdir. Katılımcılara "Bu konudaki önerileriniz nelerdir?"diye sorulduğunda ise verilen cevapların yüzde 37'sinde denetim mekanizmasının arttırılması, yüzde 23'ünde etik eğitimin verilmesi, yine yüzde 23'ünde erdemli bireyler yetiştirmek gerektiği, yüzde 8 'inde ise gümrük vergilerinin düşürülmesi dile getirilmiştir. Bazı katılımcıların görüşleri aşağıdaki gibidir:

"Etik dışı davranışların önlenmesine yönelik olarak yapılan çalışmalar yeterli değildir. Bu konudaki önerilerim ise etik eğitimden ziyade erdemli bireyler yetiştirmektir." (Katılımc1 21) "Etik dışı davranışların önlenmesine yönelik olarak yapılan çalışmalar yeterli değildir. Bu konudaki önerilerim denetimlerin daha sık yapılması, görev bilincinin aşılanması için daha fazla hizmet içi eğitimin ve etik eğitimin verilmesi. Denetleme mekanizması tarafsızlık ilkesine bağlı ve liyakatli olmalıdır." (Katılımcı 22)

"Yeterli olduğunu düşünmüyorum. Bu konudaki önerilerim ise sık aralıklarla etik ile ilgili eğitimler verilmeli ve gümrük vergileri düşürülmelidir." (Katılımc1 17)

Tablo 8. Yedinci Soru ve Katılımcıların Bu Soruya Verdikleri Cevaplar

\begin{tabular}{llll}
\hline Soru & Cevaplar & S1klık & Yüzde \\
\hline $\begin{array}{l}\text { Gümrük idarelerinde etik } \\
\text { dışı davranışların }\end{array}$ & Kurallara riayet edilmesi & 3 & 33 \\
$\begin{array}{l}\text { olduğunu } \\
\text { düşünmüyorsanız, bunun }\end{array}$ & Kamera takip sisteminin artı̧ı & 3 & 33 \\
$\begin{array}{l}\text { nedenini açıklayabilir } \\
\text { misiniz? }\end{array}$ & $\begin{array}{l}\text { verilmiş olması } \\
\text { Denetimin sıkılaştırılması }\end{array}$ & 2 & 23 \\
\hline
\end{tabular}

Tablo 8' de "Gümrük idarelerinde etik dışı davranışların olduğunu düşünmüyorsanız, bunun nedenini açılayabilir misiniz?" sorusuna verilen cevaplar görülmektedir. 9 katılımcının verdikleri cevaplar şu şekildedir; yüzde 33 "kurallara riayet edilmesi", yüzde 33 "kamera takip sisteminin artış", yüzde 23 "ilgili personele gerekli eğitimin verilmiş olması" ve yüzde 11 ise "denetimin sıklaşması". Bazı katılımcıların görüşleri aşağıdaki gibidir:

"Kurallara riayet edildiğinden ötürü etik dışı davranış yoktur." (Katılımcı 30)

"Çalışan personel kurallara riayet ettiğinden ötürü etik dışı davranışlar yoktur." (Katılımc1 14)

"Gümrük idarelerinde gerekli etik eğitimler verildiğinden ötürü etik dişı davranışlar yoktur."

(Katılımc1 24)

\section{Tartışma ve Sonuç}

Küreselleşen dünya ile birlikte dış ticaretin artışı, buna bağlı olarak eşya dolaşımının ve ticari hareketliliğin yoğun yaşanması gümrük idarelerindeki iş yükünü de arttırmaktadır. Buna ek olarak gümrük idareleriyle iş yapan firmaların gerekli işlemlerin daha hızlı yapılmasını talep etmeleri ile gümrük memurlarının yetki ve sorumlulukları da göz önünde bulundurulduğunda etik dişı davranışların arttığ1 gözlemlenmektedir (Ateş vd. 2009: 399). Yapılan çalışmalar (Adaman vd. 2003; TESEV, 2015; TEID, 2016) incelendiğinde kamuoyunun gözünde kamu ve özel kurumlar arasında gümrük idarelerinin etik dış1 davranışların yaşandığ kurumların başında geldiği görülmektedir. Bu nedenle bu araştırma, 
Mersin taşra gümrük idaresi ile iş yapan firmaların etik dışı davranışlar ile karşılaşıp karşılaşmadığını, karşılaştılar ise ne tür davranışlar ile karşılaştıklarını ortaya çıkarmak ve bu tür davranışları ortadan kaldırabilecek öneriler sunmak amacıyla yapılmıştır.

Araştırma sonuçlarına göre; etik dışı davranış tanımlanırken katılımcıların yarısından fazlası toplumun benimsemediği (gayri ahlaki) davranışlar, daha azı da kanun ihlali ve genel geçer doğruların ihlali şeklinde açıklamalarda bulunmuşlardır. Katılımcılardan etik kavramına dair elde edilen bulgular etik alan yazınında etiğin tanımında yer alan ifadeler olup çıkan sonuçlar Arslan ve Berkman (2009), Özdevecioğlu (2005) ve Hakeri'nin (2006) çalışmalarını destekler niteliktedir. Gümrük idareleri ile iş yapan insanların etiğin ne olduğunu bilmeleri, bu konuda bilinç sahibi olmaları iyi bir özellik olsa da, asıl önemli olan bu bilincin davranışlara yansıması ve etiğe uygun davranılmasıdır. Çünkü davranışa yansımayan bilinç tek başına bir işe yaramamaktadır.

Araştırmada katılımclar ağırlıklı olarak gümrük idarelerinde etik dışı davranışların görüldüğünü belirtmişlerdir. Adaman vd. (2003), hem hane halkının hem de iş dünyasının gümrükte etik dışı davranışların olduğuna inandığını, her iki oranın da yüksek olduğunu ancak iş dünyasındaki inancın hane halkındaki inançtan daha yüksek olduğunu ifade etmiş̧lerdir. Katılımcılardan elde edilen veriler alanyazın kısmında aktarılan çeşitli gazete haberleri, Akçay'ın (2009), Ateş vd. (2009), Çalık'ın (2012), TESEV'in (2015), çalışmalarla paralellik göstermektedir.

Etik dışı davranışlarla karşılaştığını belirten katılımcıların yarısından fazlası etik dışı davranışların gümrük idarelerinin bütün birimlerinde olduğunu ifade ederken, geri kalan katılımcılar da gümrük muayene birimi ve gümrük muhafaza biriminden söz etmişlerdir. Etik dışı davranışların özellikle bu birimlerde görülmesinin nedeni sorulduğunda ise; bu katılımcıların yarıya yakını yetkinin kötüye kullanımı ve ekonomik çıkar sağlamayı, diğerleri de mükelleflerle yakınlaşma ve denetlenmemeyi neden olarak göstermişlerdir. Etik dışı davranışların gümrük muayene biriminde görülmesinin nedeni olarak, mükelleflerle yüz yüze iletişimden kaynaklanan samimiyet ve yakınlaşma gösterilebilmektedir. Bu konuda Ateş vd. (2009), iş sahipleri ile memurların yüz yüze görüşmesi ve birebir muhatap olmasının etik dışı davranışların oluşmasında önemli bir etken olduğunu dile getirmişlerdir. Çalık (2012) da iş takipçilerinin varlığı ile denetim yetersizliğinin etik dışı davranışların oluşmasındaki rolüne dikkat çekmektedir. Gümrük idarelerinde bazı birimlerde görülen yüz yüze iletişimi biraz daha azaltmak adına e-devlet sisteminde olduğu gibi, yapılması mümkün olan işler, otomasyon sistemi ile yerine getirebilir. Bazı konularda memurların inisiyatifi azaltılabilir. Tüm birimlerde daha etkin bir kamera kayıt istemi kurulabileceği gibi denetimler de arttırılabilir.

Gümrük idaresinde etik dışı davranış olduğunu düşünen katılımcıların yarıdan fazlası gümrük idarelerinde en çok görülen etik dişı davranışları adam kayırma olarak belirtirken, yarıya yakın bir kısım da rüşvetten bahsetmiştir. Adaman vd. (2003), Ateş vd. (2009) ile Pustu'nun (2011), TESEV'in (2015), çalışmaları rüşvet ve adam kayırma bakımından araştırma sonucunu destekler nitelikte sonuçlara ulaşan çalışmalardır. Bu konuda caydırıcı önlemlerin alınmasının dışında cezaların ağırlaştırılmasının, kurum içinde ve kurum dışında şikâyet mekanizmaları oluşturulmasının faydalı olabileceği düşünülmektedir.

Araştırmada elde edilen bulgular sonucunda, etik dışı davranışların nedenlerinin eğitimsizlik, yetki ve sorumluluğun kötüye kullanılması, daha çok kazanma arzusu, ahlaki 
yoksunluk ve maaşların yetersiz olması olduğu tespit edilmiştir. Ateş vd.(2009) hem gümrük personeli hem de vatandaşlar ile yaptığı çalışmalarında, gümrük personelinin büyük çoğunluğu hizmet içi eğitim almadığını, alanlar da bu eğitimin yetersiz olduğunu belirtmişlerdir. Aynı çalışmada, etik dışı davranışların nedenleri gümrük personeli açısından sosyal ve mali hakların özellikle maaşların düşüklüğü, iş yükünün fazla ve çalışma ortamının kötü olması olarak ortaya konmuştur. Çalık (2012) da çalışmasında benzer sonuçlar elde etmiştir. Etik eğitim, okulların müfredatında yer almalı ve küçük yaşlardan itibaren kişiler bu konuda bilinçlendirilmelidir. Ek olarak, gümrük idarelerinde de hizmet içi eğitim çerçevesinde yeterli düzeyde etik eğitim verilmeli, bu konunun önemi ve etik davranılmaması sonucu oluşabilecek durumlar vurgulanmalıdır. Gümrük idaresinde çalışanların yetki ve sorumlulukları, sosyal ve ekonomik hakları belirli aralıklarla gözden geçirilmeli ve gerekli düzenlemeler yapılmalıdır.

Araştırmada, etik dışı davranışların önlenmesine yönelik yapılan çalışmaların yeterli olmadığını katılımcıların yarısından fazlası dile getirmiştir. Etik dışı davranışların önlenmesine yönelik katılımcı önerileri; ağırlıklı olarak denetim mekanizmasının arttırılması, etik eğitimlerin daha çok verilmesi ve en başta erdemli bireyler yetiştirmek şeklindedir. Çalık'ın (2012) çalışması da araştırma sonuçlarıyla benzerlik göstermektedir. Ateş vd. (2009) yaptığı çalışmada, personel hizmet içi eğitimi yeterli görmese de idarenin etik dışı davranışlarla ilgili çabalarını yeterli bulduğunu ifade etmiştir. Alanyazında aktarılan gazete haberleri, etik konusunda çıkarılan mevzuat hükümleri ve bu konudaki raporlar incelendiği zaman başta Gümrükler Genel Müdürlügü olmak üzere gümrük teşkilatının tüm birimlerinin etik dışı davranışların üstüne gittiği, bu konunun takipçisi olduğu ve suçluların cezalandırılması için büyük çaba gösterdiği görülmektedir. Etik dışı davranışların önüne geçebilmek için gösterilen bu çabanın arttırılarak devam etmesi hatta daha farklı önlemler alınması gerekmektedir.

Araştırmada gümrük idarelerinde etik dışı davranışların olmadığını belirten katılımcılar da olmuştur. Katılımcıların çoğu bunun nedenini genel itibariyle gümrük idarelerinde kamera takip sisteminin artışı ve kurallara riayet edilmesi şeklinde ifade ederken, diğer katılımcılar ise ilgili personele gerekli eğitimin verilmesi ve denetimin sıklaşması biçiminde beyanda bulunmuşlardır. Kamera takip sisteminin artışının, verilen etik eğitimlerin ve denetimin sıkılaştırılmasının, etik dışı davranışların azalmasında etkisi olsa da yapılanların yeterince etkili olmadığ gerek gazete haberleri gerekse bu konuda yapılan çalışmalar (Adaman vd., 2003; Ateş vd., 2009; Pustu, 2011; Çalık, 2012) ve raporlardan (TESEV, 2015; TEİD, 2016) anlaşılmaktadır. Alınacak önlemlerin etiksel problemlerin azalması yönünde olumlu dönüşleri olsa da kalıcı çözümlerin gerçekleşebilmesi insan haklarına saygıll, hukuk kurallarına bağlı erdemli bireylerin yetiştirilmesiyle gerçekleştirilebilmektedir. Bu nedenle bireylere aile, okul ve meslek yaşamlarında etik konusunda iyi ve yeterli eğitimin verilmesi önem taşımaktadır.

Araştırma çeşitli kısıtlara sahiptir. İlk olarak araştırma zaman ve maliyet kısıtlarından ötürü sadece Mersin ilinde bir gümrük idaresi baz alınarak yapılmıştır. İkinci olarak örnekleme sadece Mersin Taşra Gümrük İdaresi ile iş yapan firmalar dahil edilmiştir. Araştırma tasarlanırken gümrükle iş yapan firmalar dışında gümrük personelinin de araştırmanın örneklemi içerisinde yer alması, böylelikle de iş yapan iki tarafın karşılıklı görüşlerine yer verilmesi düşünülmüştür. Ancak yapılan resmi yazışmalar neticesinde gümrük personeli ile görüşme yapmak için izin alınamamış, bu nedenle sadece görüşmeye istekli, özel firmalar 
örnekleme dahil edilebilmiştir. Üçüncü olarak, araştırmada sadece nitel yöntemlerden yüz yüze derinlemesine görüşme yöntemi kullanılmıştır. Sayılan tüm bu kısıtlardan ötürü araştırma sonuçlarının Türkiye'ye genellenmesi mümkün değildir.

İleriki zamanlarda bu konuda çalışmak isteyen araştırmacılara, eğer izin alabilirlerse sadece gümrükle iş yapanlarla değil aynı zamanda gümrük personeli ile de çalışmaları, birden fazla gümrük idaresinde çalışma yürütüp etik davranış anlamında aradaki farkları ve benzerlikleri ortaya çıkartmaları, nitel ve nicel araştırma yöntemlerini bir arada kullanarak daha detaylı sonuçlara varmaları tavsiye edilebilir.

\section{Kaynakça}

Adaman, F., Çarkoğlu, A., \& Şenatalar, B. (2003). İş dünyası gözünden Türkiye'de yolsuzluğun nedenleri ve önlenmesine ilişkin öneriler, TESEV Yayınları, İstanbul.

Akçay, S. (2009). Gümrüklerde yolsuzluk: Dışsal nedenleri, sonuçları ve önlemleri, İş Ahlakı Dergisi, 2 (7), 7-20.

AKİB Aktüel (2018). Mersın limanı'nda yük trafiği 2,9 milyon tona yükseldi, Erişim adresi: https://www.akib.org.tr/files/downloads/Akib_Aktuel/akib-85.pdf

Aktan, C., C. (1993). Politikada rant kollama, Amme İdaresi Dergisi, 26 (4), 121-140.

Aktan, C., C. (1996). 21. yüzyıl için yeni toplumsal sözleşme, T Yayınları, İstanbul.

Aktan, C., C. (1999). Ahlak ve ahlak felsefesi, ARI Düşünce ve Toplumsal Gelişim Derneği Yayını, İstanbul.

Aktan, C., C. (2001). Yolsuzlukla mücadele stratejileri, Hak-İş Yayınları, Ankara.

Aktan, C., C. (2002). Siyasal ahlak ve siyasal yozlaşma, Coşkun Can Aktan (Editör), Yolsuzlukla Mücadele Stratejileri, Hak-İş Yayınları, Ankara.

Ali, M., S., \& Mdhillat, M. (2015). Does corruption impede international trade? new evidence from the EU and the MENA countries Journal of Economic Cooperation and Development, 36 (4), 107-120.

Arslan, M. \& Berkman, Ü. (2009). Dünyada ve Türkiye'de iş etiği ve etik yönetimi, TÜSİAD, İstanbul.

Ateş, H., Güloğlu, T., \& Es, M. ( 2009). Yolsuzluğun Önlenmesi için Etik Projesi cilt2: Gümrük Hizmetlerinde Etik. Erişim adresi: http://etik.gov.tr/Portals/0/Kamu\%20Etigi\%20Akademik\%20Arastirmalari\%20Kitabi\%20C ilt\%202.pdf), (01.01.2018).

Başbakanlık Gümrük Müsteşarlığı, (2008). Gümrüklerde Yolsuzlukla Mücadele Dürüstlük ve Etik İlkeler, Erişim adresi: https://www.gtb.gov.tr/data/5208d1c7487c8e14044289f8/etik\%20raporu-son.doc

Cevizci, A. (2002). Etiğe giriş, Paradigma Yayınları, İstanbul.

Coşkun, H. (2010). Kamu etiği ve gümrük personeli meslek etik ilkeleri üzerine, Gümrük Bülteni, 2, 19-24.

Coşkun, R., Altunışık, R., Bayraktaroğlu, S., \& Yıldırım, Engin (2015). Araştırma yöntemleri, Sakarya Yayıncılık, Sakarya. 
Çalık, K. (2012). Kamu yönetiminde etik değerlerden sapma: bir kamu örgütü üzerine alan araştırması (Yüksek lisans tezi, Gazi Üniversitesi, Ankara). Erişim adresi: http://tez2.yok.gov.tr/

Çevikbaş, R. (2006). Yönetimde etik ve yozlaşma", İktisadi İdari Bilimler Dergisi,20 (1), 265-289.

Dünya Bülteni (2015). Gümrükte Rüşvet Operasyonu, Erişim adresi: http://www.dunyabulteni.net/haber/329500/gumrukte-rusvet-operasyonu-5-tutuklama.

Gezikol, B., Tunahan, H. (2018). Algılanan yolsuzluk ile diş ticaret ve doğrudan yabancı yatırım arasındaki ilişkinin uluslararası endeksler bağlamında ekonometrik analizi, The Journal of Operations Research, Statistics, Econometrics and Management Information Systems, 6 (1), 117-132

Guthire, J., Dumay, J. \& Riccerı, F. (2004). Using content analysis as a Research method toinguirein to intellectual capital reporting, Journal of Intellectual Capital, 5, 285.

Hakeri, H. (2006). Türk ceza hukukunun temel kavramları (2. bs.), Seçkin Yayıncılık, İstanbul.

Hürriyet (2018). Dilucu Gümrük Kapısı'nda “yolsuzluk” operasyonu: 40 gözaltı, Erişim adresi: https://www.hurriyet.com.tr/dilucu-gumruk-kapisinda-yolsuzluk-operasyonu40770412 .

İnal, G., Y. (2012). Kamu yönetiminde merkezileşmiş bir otorite olarak kamu görevlileri etik kurulu (Yüksek lisans tezi, Pamukkale Üniversitesi, Denizli). Erişim adresi: http://tez2.yok.gov.tr/

Jancsics, D. (2019). Border Corruption, Public Integrity, 20 (4), 406-419

Kaplan, Ç. (2009). Kamu yönetiminde etik ve kamu çalışanlarının etik kavramını algılayışları, Süleyman Demirel Üniversitesi İktisadi İdari Bilimler Fakültesi Dergisi, 14(3), 343355.

Köprü, B. (2007). Türk kamu yönetiminde etik değerlerden sapma ve yönetsel yozlaşma (Yüksek lisans tezi, Gazi Üniversitesi, Ankara). Erişim adresi: http://tez2.yok.gov.tr/

Mersin Gümrük Müşavirleri Derneği (2018). Mersin Gümrük Müşavirliğine bağlı firma sayıs1, Erişim adresi: http://www.mergumder.org.tr.

Miloshoska, D., \& Vasileska, L. (2012). Customs professional integrity: the case of the republic of macedonia, 4 th International Conference On Governance Fraud Ethics And Social Responsibility, At Alanya, Turkey

Onogwu, D. (2018). Corruption and the efficiency of customs clearance process in selected countries. Review Public Administration Management, 6 (257),1-8.

Öktem, M., K. \& Ömürgönülşen, U. (2005). Kamu yönetiminde etik çalışmalarına yönelik genel bir çerçeve arayışı içinde siyasette ve yönetimde etik sempozyumu, Sakarya Üniversitesi İktisadi Ve İdari Bilimler Fakültesi, 231-237.

Özdevecioğlu, M. \& Aksoy, M., S.(2005). Organizasyonlarda sabotaj: Türleri, amaçları, hedefleri ve yönetimi, Cumhuriyet Üniversitesi İktisadi ve İdari Bilimler Dergisi, 6 (1), 95-115.

Özsemerci, K. (2003). Türk kamu yönetiminde yolsuzluklar, nedenleri, zararları ve çözüm önerileri (1. bs.), Sayıştay Yayın İşleri Müdürlüğü, Ankara.

Pustu, Y. (2011). Kamu yönetiminde etik bir sorun olarak rüşvet (Doktora tezi, Gazi Üniversitesi, Ankara). Erişim adresi: http://tez2.yok.gov.tr/ 
Tanriseven, H. (2006). Hukuksal ve yönetsel açıdan rüşvet: nedenleri ve çözüm önerileri (Yüksek lisans tezi, Dicle Üniversitesi, Diyarbakır). Erişim adresi: http://tez2.yok.gov.tr/

Tekin, H., H. (2006). Nitel araştırma yönteminin bir veri toplama tekniği olarak derinlemesine görüşme, İstanbul Üniversitesi Edebiyat Fakültesi Sosyoloji Dergisi, 3 (13), 101116.

Tepe, H. (2004). Doğu-batı düşünce dergisi - bir felsefe dalı olarak etik (3. Bs.), Doğu Batı Yayınları, Ankara.

Transparency International (2019). Corruption perceptıons, Erişim adresi:Index2019.https://www.transparency.org/files/content/pages/2019_CPI_Report_EN. pdf (10.04.2020)

TRT Haber (2020). Bulgaristan-Sırbistan sınırında yolsuzluk operasyonu: 30 kişi tutuklandı Erişim adresi: https://www.trthaber.com/haber/dunya/bulgaristan-sirbistan-sinirindayolsuzluk-operasyonu-30-kisi-tutuklandi-459379.html.

Türnüklü, A. (2000). Eğitimbilim araştırmalarında etkin olarak kullanılabilecek nitel bir araştırma tekniği: görüşme, Kuram Ve Uygulamada Eğitim Yönetimi, 24, 543-559.

Uca, N., Civelek, M. E., \& Çemberci, M. (2019). Yolsuzluk algısının gayrisafi yurt içi hasıla üzerine etkisinde lojistik performans ile küresel rekabetin ara değişken rolü: Türkiye değerlendirmesi. OPUS- Uluslararası Toplum Araştırmaları Dergisi , 10(17), 1229-126

Uluslararası Şeffaflık Örgütü Yolsuzluk Algı Endeksi, (2014). Erişim adresi: http://www.seffaflik.org/uluslararasi-seffaflik-orgutu-2014-yolsuzluk-algiendeksiaciklandi.

Uluslararası Şeffaflık Örgütü Yolsuzluk Algı Endeksi, (2016). Erişim adresi: http://www.seffaflik.org/cpi2016.

Yıldırım, A. \& Şimşek, H. (2016). Nitel araştırma yöntemleri (10. bs.), Seçkin Yayıncılık, İstanbul.

Yılmaz, D. (2012). Kamu kurumlarında etik davranış anlayışı (Yüksek lisans tezi, Yalova Üniversitesi, Yalova). Erişim adresi: http://tez2.yok.gov.tr/

Yolsuzluk Alg1 Araştırması (2016). Özel Sektör Araştırma Sonuçları, Erişim adresi: http://www.tice.org.tr/wp-content/uploads/2016/10/TE\%C4\%B0D-YolsuzlukAlg\%C4\%B1Ara\%C5\%9Ft\%C4\%B1rmas\%C4\%B1-Raporu.pdf.

Yolsuzluk Raporları, (2016). Türkiye'de Yolsuzluk Algısı. Erişim adresi: http://tesev.org.tr/wpcontent/uploads/2016/12/YolsuzlukRapor1_YolsuzlukAlgisi.pdf.

Yolsuzluk ve Yolsuzlukla Mücadele Türkiye Değerlendirme Raporu (2015), Erişim adresi.http://tesev.org.tr/wpcontent/uploads/2015/11/Yolsuzluk_Ve_Yolsuzlukla_Mucadel e_Turkiye_Degerlendirme_Raporu.pdf 